\title{
Dried Blood Spot for Developing Countries: An Opinion
}

\author{
Bhuvan Saud ${ }^{1 *}$, Bobby Thapa ${ }^{2}$ and Vikram Shrestha ${ }^{1}$ \\ ${ }^{1}$ Department of Medical Laboratory Technology, Nepal \\ ${ }^{2}$ Department of Nursing, Janamaitri Foundation Institute of Health Sciences (JFIHS), Nepal
}

Submission: March 12, 2017; Published: May 09, 2018

*Corresponding author: Bhuvan Saud, Department of Medical Laboratory Technology, Janamaitri Foundation Institute of Health Sciences (JFIHS), Hattiban, Lalitpur, Nepal, Email: link2bhuvan@gmail.com

\section{Opinion}

Health has been declared the fundamental right of the humankind worldwide. People seek health services and fulfill their health needs through different levels of health care facilities. However, this is not absolutely true in our part of the world. In context of developing countries like Nepal, its topography, limited resources (man, money, materials), lack of proper plans and policies and regular monitoring has been influencing the early diagnosis of the disease condition. These scenarios are delaying the early treatment and are ultimately increasing the morbidity and mortality rate of the population. Thus, early diagnosis is one of the important components of health care services. In remote areas, there are limited infrastructures and equipments in the laboratories. Even if there are equipments, it would be outdated or would not be in their working condition. Thus, the collected samples have to be sent to higher level of health care facilities for the investigation. Meanwhile, the topography and poor resource for the transportation of the samples to the higher level of health care facilities has been the shortcoming for the early diagnosis of the disease. In such condition, Dried Blood Spot (DBS) would be the most appropriate and highly convenient approach to overcome such shortcoming in countries like ours.

Dried blood spot is a form of biosampling where blood samples collected from the finger, heel or toe prick of neonates or vein puncture and loaded into a cellulose or polymer card paper. The blood in the card paper is then air dried for several hours and stored in low gas-permeability plastic bags with added desiccant to reduce humidity [1]. It is used to collect, store and transport sample for serological test, immunological test, toxicoand pharmacokinetic studies, metabolic profiling, therapeutic drug monitoring, forensic toxicology, or environmental contamination control [2]. DBS has become as one of the most convenient tools for the human blood sample collection with multiple benefits such as analytic measurement for more than 50 separate analytes [3], the sample is stable for months at ambient temperature or refrigeration with minimal loss of enzymatic activity [4], easy to ship zip-lock bags without maintaining a cold chain from remote to the laboratory, minimal biohazard to the operator during handling and transport. The World Health Organization has also provided DBS manual for HIV testing [5]. Thus, this method of biosampling will be very promising for the resource-poor setting developing countries.

The study conducted in Nepal showed that the sample loaded DBS cards transport normal postal delivery mean duration to be 2.25 days, sample being stable for a month at room temperature with sensitivity and specificity of HIV rapid 1 and 2 to be $88.9 \%$ and $94 \%$ respectively [6]. Currently, National Center for AIDS and STD Control, Government of Nepal collected DBS samples from 25 different sites for early diagnosis of HIV among the newborn babies born to HIV infected mother through DNA -PCR method [7]. It has also been used for the detection of Pgp3 antibody for Chlamydia Trachomatis surveillance [8]. The stability of anti-HEV IgM in stored DBS cards up to 65 days at $4{ }^{\circ} \mathrm{C}$ [9]. The sensitivity and specificity for HIV detection by DNA-PCR using DBS is found to be $95 \%$ and $100 \%$ respectively 10 . Similarly, the sensitivity for the detection of Dengue RNA is found more than $90.7 \%$ [11]. Sarkar et al. [12] proposed dried blood spot for the Bio-safety level 4 of Ebola virus transportation and diagnosis in tropical developing countries.

In conclusion, DBS could be the most proficient method of sample collection for developing countries. They requires small quantity of sample through minimal invasive procedure, sample with longer lifespan, minimal biohazard risk to handlers, easy to transport, accessible, affordable, high level of specificity and sensitivity. Despite these significant advantages, it is still minimally practiced in Nepal. However, adequate research, along with formation of plans and policies of practicing DBS for early diagnosis and treatment is required in Nepal.

\section{References}

1. https://www.cdc.gov/labstandards/pdf/nsqap/Bloodspot_ Transportation_Guidelines.pdf

2. Grüner N, Stambouli O, Ross RS (2015) Dried Blood Spots - Preparing and Processing for Use in Immunoassays and in Molecular Techniques. J Vis Exp (97): e52619. 
3. https://doi.org/10.1093/jn/131.5.1631S

4. De Jesus VR, Zhang XK, Keutzer J, Bodamer OA, Mühl A, et al. (2009) Development and Evaluation of Quality Control Dried Blood Spot Materials in Newborn Screening for Lysosomal Storage Disorders. Clinical Chemistry 55(1): 158-164.

5. http://www.who.int/hiv/topics/drugresistance/dbs_protocol.pdf

6. Thapa B, Koirala S, Upadhaya BP, Mahat K, Malla S, et al. (2011) Nationa External Quality Assurance Scheme for HIV Testing using Dried Blood Spot: A Feasibility Study. Saarc J Tuber Lung Dis Hiv/Aids 8(2): 23-27.

7. http://www.aidsdatahub.org/sites/default/files/publication/NCASC Factsheet_5_PMTCT_2017.pdf

8. https://doi.org/10.1371/journal.pntd.0005003
9. Singh MP, Majumdar M, Budhathoki B, Goyal K, Chawla Y, et al. (2014) Assessment of dried blood samples as an lternative less invasive method for detection of hepatitis E virus marker in an outbreak setting. J Med Virol 86: 713-719.

10. Jacob SM, Anitha D, Vishwanath R, Parameshwari S, Samuel NM (2008) The use of dried blood spots on filter paper for the diagnosis of HIV1 in infants born to HIV seropositive women. Indian J Med Microbiol 26(1): 71-74.

11. Snijdewind IJ, van Kampen JJ, Fraaij PL, van der Ende ME, Osterhaus AD,et al. (2012) Current and future applications of dried blood spots in viral disease management. Antiviral Res 93: 309-321.

12. Sarkar S, Singh MP, Ratho RK (2015) Dried blood spot for Ebola testing in developing countries. Lancet Infect Dis 15(9): 1005.

\begin{tabular}{l} 
Your next submission with Juniper Publishers \\
will reach you the below assets \\
- Quality Editorial service \\
- Swift Peer Review \\
- Reprints availability \\
- E-prints Service \\
- Manuscript Podcast for convenient understanding \\
- Global attainment for your research \\
- Manuscript accessibility in different formats \\
( Pdf, E-pub, Full Text, Audio) \\
- Unceasing customer service \\
Track the below URL for one-step submission \\
https://juniperpublishers.com/online-submission.php \\
\hline
\end{tabular}

